\title{
H6N1 bird flu: new emerging infection that the neurologist has to prepare for management
}

Gripe aviária H6N1: uma nova infecção emergente que o neurologista tem que estar preparado para acompanhar

Sir,

The newest emerging infection of our world is the new H6N1 bird flu, which was firstly reported this month (November, 2013) from Taiwan ${ }^{1,2}$. Although there is only one published case, it is expected that there will be the continuum. For any new emerging infection, Wiwanitkit and Wiwanitki previously noted for the necessity for the neurologist to focus on the possible neurological complication ${ }^{3}$. For the present scenario of emerging H6N1 influenza, the attention is also needed. Based on present information, the indexed human case showed no specific neurological manifestation. In the previous report, in animal model, the H6N1 bird flu affected the neurological system less than H5N1 bird flu done $e^{4}$. Nevertheless, since the infection is a new cross species infection to human, the effect of the new virus is still unknown and further study on this topic is suggested.

Err Hai ${ }^{1}$, Wiwanitkit Viroj ${ }^{2}$

\section{References}

1.

Yuan J, Zhang L, Kan X, Jiang L, Yang J, Guo Z, Ren Q. Origin and molecular characteristics of a novel 2013 avian influenza A (H6N1) virus causing human infection in Taiwan. Clin Infect Dis 2013;57:1367-1368.

2. Shi W, Shi Y, Wu Y, Liu D, Gao GF. Origin and molecular characterization of the human-infecting H6N1 influenza virus in Taiwan. Protein Cell 2013;4:846-853.
3.

Wiwanitkit S, Wiwanitkit V. Brain involvement in H7N9 bird flu: a topic for consideration. Arq Neuropsiquiatr 2013;71:825.

4. Leneva IA, Goloubeva O, Fenton RJ, Tisdale M, Webster RG. Efficacy of zanamivir against avian influenza $A$ viruses that possess genes encoding $\mathrm{H} 5 \mathrm{~N} 1$ internal proteins and are pathogenic in mammals. Antimicrob Agents Chemother 2001;45:1216-1224.

'Sanitation 1 Medical Academic Center, Bangkok Thailand;

${ }^{2}$ Visiting professor, Hainan Medical University, China; Visiting professor, Faculty of Medicine, University of Nis, Serbia; Adjunct professor, Joseph Ayobabalola University, Nigeria.

Correspondence: Hai Err; Sanitation 1 Medical Academic Center; Bangkok Thailand; E-mail: haierbj@live.com

Conflict of interest: There is no conflict of interest to declare.

Received 18 November 2013; Accepted 09 December 2013. 